\title{
Yield Performance of Some Advanced Aromatic Rice Genotypes in Guyana
}

\author{
Mahendra Persaud ${ }^{1}$, Nandram Gobind ${ }^{1}$, Violet Henry ${ }^{1}$, Rajendra Persaud ${ }^{1,}$, Oudho Homenauth $^{2}$ \\ ${ }^{1}$ Guyana Rice Development Board, Rice Research Station, East Coast Demarara, Guyana \\ ${ }^{2}$ National Agricultural Research and Extension Institute, East Coast Demarara, Guyana
}

Email address:

rajpersaud25@yahoo.com (R. Persaud),rpersaud@grdb.gy (R. Persaud)

*Corresponding author

To cite this article:

Mahendra Persaud, Nandram Gobind, Violet Henry, Rajendra Persaud, Oudho Homenauth. Yield Performance of Some Advanced Aromatic Rice Genotypes in Guyana. American Journal of Agriculture and Forestry. Vol. 9, No. 5, 2021, pp. 312-318.

doi: 10.11648/j.ajaf.20210905.15

Received: July 31, 2021; Accepted: September 10, 2021; Published: October 29, 2021

\begin{abstract}
Breeding for quality traits is one of the major objectives of the Rice Breeding programs in Guyana and many other countries that are self-sufficient in rice production. Aromatic rice constitutes a special group of rice which is known as the best quality of rice worldwide. It is known for its nut/popcorn-like aroma and taste. This group is estimated to account for only 15$18 \%$ of the total rice trade on the world market. They are rated as the best in quality and sell for a much higher price than high quality non-aromatic rice on the international market. Due to this fact, considerable attention has been given towards developing aromatic varieties with the view of allowing the Guyanese farmers the opportunity to enter this niche aromatic rice market and enjoy the premium price offered. So far, the breeding program has released one aromatic variety (viz. GRDB 13) for commercial cultivation in Guyana. Further, more than 200 breeding lines were evaluated and of which 14 elite genotypes were selected for further testing of their yielding ability and agronomic traits for developing and released as an aromatic rice variety. These strains were tested during the spring crop of 2019 at Rice Research Station, Burma, Mahaicony, East Coast Demerara, Guyana in a Randomized Complete Block Design with three replications. The study identified three high yielding genotypes viz., G13-113 (7840.5 kg/ha), G13-114 (7761.8 kg/ha) and G17-138 (7526.5 kg/ha) with statistically similar to the high yielding ability as the aromatic check variety, GRDB 13. In addition, all except two genotypes (G13-116 and G17-138), showed good tolerance to lodging. There was significant variability among the aromatic genotypes evaluated for days to maturity, plant height, tillers, grain length, fertility of grains, panicle length and grain weight. Also the aromatic genotypes showed similar excellent milling and cooking qualities as the local varieties.
\end{abstract}

Keywords: Aromatic, Rice, High Yielding, Lodging Tolerant

\section{Introduction}

Rice is the main food crop in Guyana and major foreign exchange earner for agriculture. It contributes $3.3 \%$ to the gross domestic product (GDP) and approximately $20.5 \%$ of the agricultural GDP in 2020 [17]. Guyana exported more than $75 \%$ of its production in 2020 [17]. Grain quality is of great importance to ensure the export markets are maintained and to provide an opportunity to bargaining for a higher price than the average world market price. Aromatic rice forms a special group of rice which is known as the best quality of rice worldwide [18]. It is known for its nut/popcorn-like aroma and taste [18]. Aromatic rice contains several bio-chemicals, the most important is 2-acetyl-1-pyrroline (2AP) which is responsible for the aroma $[8,21]$. Some of the most popular varieties of aromatic rice include ambemohar, basmati, jasmine, etc. Aromatic rice is known to attract a higher premium prices on the international market (approximately 950-1200 USD/ton) as compared to ordinary, non-aromatic, rice (which is 320 to $500 \mathrm{USD} /$ ton) [6]. Therefore, it is reasonable to assume that farmers can receive a $50 \%$ share of the increase in profits derived from such rice which can translates to an additional $200 \mathrm{USD} / \mathrm{ton}$ of paddy. Also, aromatic variety utilizes a similar cultivation and agronomic practices as well as, it has similar yielding ability as the 
existing non-aromatic varieties and therefore no noticeable increase in production cost is foreseen. GRDB has recognised the tremendous financial returns that can be garnered from the exportation of aromatic rice [14], Taking into consideration the increasing demand for aromatic rice on the international market [14] it is reasonable to believe that Aromatic rice can be the game changer of the face of Guyana's' rice industry.

Breeding for aroma in rice has always been an uphill task for breeders due to the narrow genetic base, poor combining ability of the trait, low yielding ability, late maturity and the recessive nature of the genes involved [1]. However, due to the increasing demand by importing countries for aromatic rice, there has been a growing focus and attention to develop the aromatic breeding program. In view of this, Guyana has embarked on a breeding program to develop its own aromatic rice to allow farmers an opportunity to enter the niche aromatic rice market and enjoy the higher price for it aromatic rice. It first Aromatic Rice Variety (GRDB 13) was released in 2015. The selections and testing are on the way for a second Aromatic rice variety. In this background fourteen superior breeding lines were selected from the breeding nursery of over 200 genotypes, for advanced yield testing to identify promising strains for possible release as an aromatic variety for farmers to cultivate in Guyana.

\section{Materials and Method}

The investigation was carried out at the Rice Research Station, Burma Mahaicony by the Guyana Rice Development
Board during the spring crop of 2019. Fourteen advanced Aromatic breeding lines were tested against two commercial varieties (Table 1). The experiment was set up using a Randomised Complete Block Design (RCBD) with three replicates under lowland irrigated field conditions. Genotypes were sown in a $24 \mathrm{~m}^{2}$ plots size at a seed rate of $157.2 \mathrm{~kg} \mathrm{ha}^{-1}$ (378 g per plot). Fertilizer was applied at a rate of $185 \mathrm{~kg} \mathrm{~N} \mathrm{ha}^{-1}+84 \mathrm{~kg} \mathrm{P}_{2} \mathrm{O}_{5} \mathrm{ha}^{-1}+84 \mathrm{~kg} \mathrm{~K}_{2} \mathrm{O}$ ha $^{-1}$. Weeds, pest and disease control was carried out using standard recommended chemicals at the GRDB recommended rates and timings. Field sanitation and routine husbandry practices were followed throughout the trial duration.

\subsection{Data Collection}

Plant height, tiller per meter square, lodging incidence, grain yield $\left(\mathrm{kgha}^{-1}\right)$, days to maturity, panicle length, fertility, 1000 grain weight, head rice recovery from paddy, head rice recovery from cargo, percentage of chalkiness, grain length expansion, grain width expansion and alkaline spreading value of rice were measured, collected and recorded for the fourteen advance aromatic rice genotypes and the two check cv. GRDB 13 and GRDB 15.

\subsection{Statistical Analysis}

The variance of data was analysed using analysis of variance (ANOVA) with Statistix 10 software, and grand mean values for traits were compared according to Least Significant Difference (LSD) statistical test.

Table 1. List of all entries and check varieties tested during spring Crop, 2019.

\begin{tabular}{lllll}
\hline S. N & Strain & Designation & Parentage & Aroma Present \\
\hline 1. & G13-112 & GR 1562-25-16-2-1-2-1 & GR1107-10-2-1-2/G98-135 & Strong \\
2. & G13-113 & GR 1562-25-26-1-1-2-1 & GR1107-10-2-1-2/G98-135 & Moderate \\
3. & G13-114 & GR 1562-25-26-1-1-2-1 & GR1107-10-2-1-2/G98-135 & Moderate \\
4. & G13-115 & GR 1568-31-9-1-1-1-1 & GR1107-10-2-1-2/FG07-174 & Strong \\
5. & G13-116 & GR 1568-31-9-1-1-2-1 & GR1107-10-2-1-2/FG07-174 & Mory strong \\
6. & G13-117 & GR 15678-32-3-2-2-1-1 & GR1107-10-2-1-2/FG07-174 & Strong \\
7. & G13-118 & GR 1568-32-3-2-2-2-1 & GR1107-10-2-1-2/FG07-174 & Strong \\
8. & G13-123 & GR1580-43-23-1-1-1-2 & ADRON/FG07-182 & Moderate \\
9. & G17-135 & GR1660-6-10-2-2-1-1-2-1-1-1-1 & GR1576-39/ADRON 102 \\
10. & G17-136 & GR1660-6-10-2-2-1-1-2-1-1-1-3 & GR1576-39/ADRON 102 \\
11. & G17-137 & GR1676-22-1-2-1-2-2-1-1-1-1-1 & GR1107-10-2-1-1-2/ADRON 102 \\
12. & G17-138 & GR 1678-24-39-1-1-1-2-2-1-1-1 & GR1117-12-2-3-4-3-2-1/ADRON 102 \\
13. & Aromatic Gold & NA & NA & Moderate \\
14. & Aromatic Straw & NA & NA & Modery strong \\
15. & GRDB FL 15 (check) & & & Moderate \\
16. & GRDB 13 (check) & & & Absent \\
\hline
\end{tabular}

NA $=$ Not Available.

\section{Results and Discussion}

In the presented study, 14 elite advance aromatic rice strains were tested against two local check varieties (GRDB 13 and GRDB 15). The GRDB 15 is not an aromatic variety rather a newly high yielding non-aromatic rice genotype while the GRDB 13 is Guyana's first and only released aromatic variety.

In Figure 1 it was observed that the high yielding check variety (GRDB 15) obtained the highest yield followed by the aromatic check variety and then the evaluated strains G13-113, G13-114 and others while strains G 13-123 and G 13-115 yielded the least. As indicated in table 1, the high yielding check variety (GRDB 15) produces yields $\left(8850.0 \mathrm{~kg} \mathrm{ha}^{-1}\right)$ that are significantly $(\mathrm{P}=0.05)$ higher than all the strains tested except for the aromatic check variety (GRDB 13) while there was no significant difference between the aromatic check variety (GRDB 13) and strain G 13-113, G 13-114 and G 13-138 with 
strain G 13-113 yielding the highest (7840.5 $\left.\mathrm{kg} \mathrm{ha}^{-1}\right)$. Strains G $13-115$ and $G$ 13-123 yielded the least with $6662.0 \mathrm{~kg} \mathrm{ha}^{-1}$ and $6587.0 \mathrm{~kg} / \mathrm{ha}$, respectively. The yields obtain by these strains were all superior to that obtained by Hossain and Islam [9], where they recorded the highest yield of $3200 \mathrm{~kg} \mathrm{ha}^{-1}$ from one of the ten most popular aromatic varieties studied in Bangladesh. In another study carried out by Rashid and Kumar [15] where they evaluated seven aromatic varieties for their yielding ability and gained the highest yield of $2540.0 \mathrm{~kg} \mathrm{ha}^{-1}$ for one variety while the lowest being $1830.0 \mathrm{~kg} \mathrm{ha}^{-1}$.

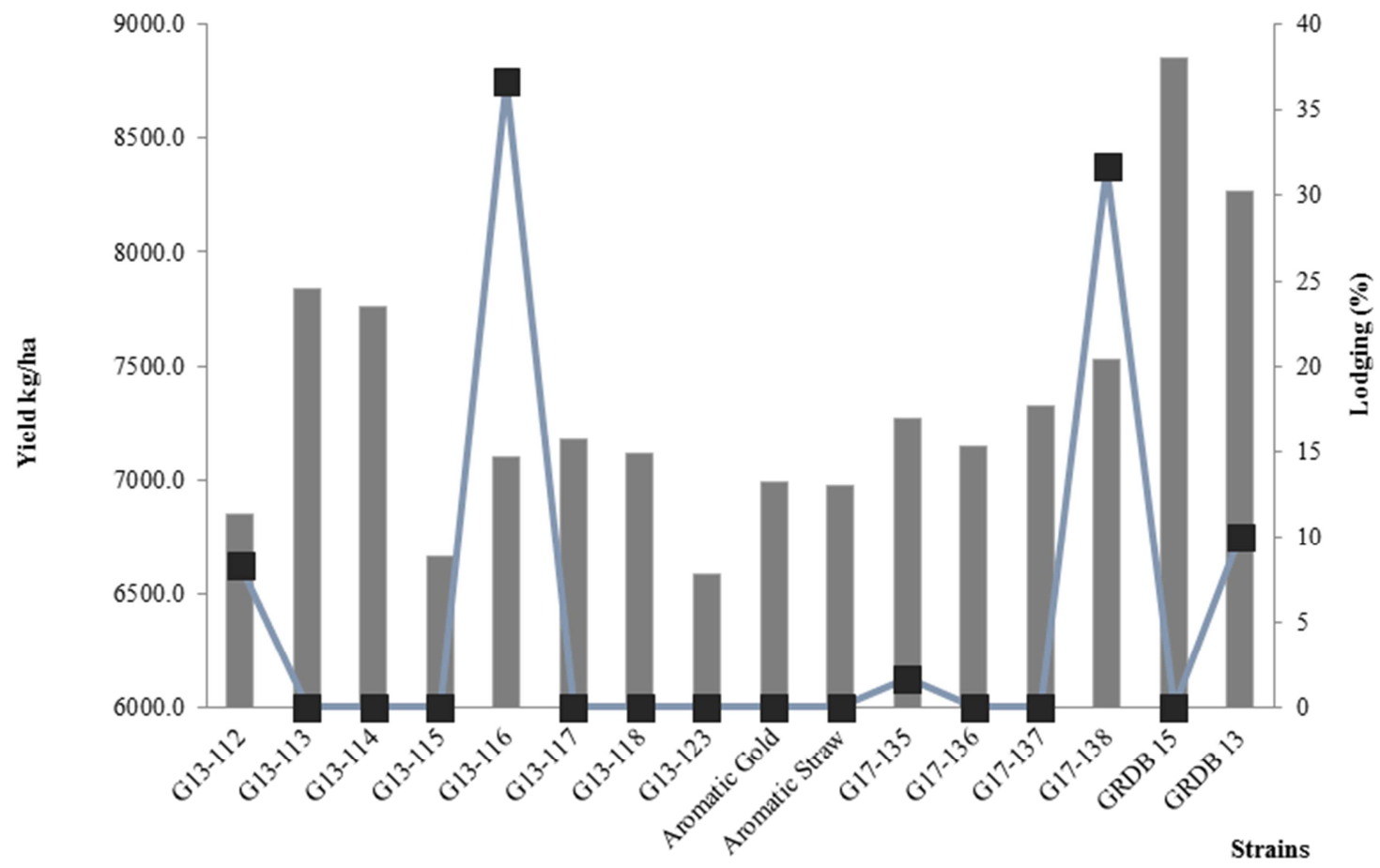

Figure 1. Grain yield and lodging comparison for strain tested during the spring crop of 2019.

Also seventy two percent of the strains (G13-113, G13-114, G13-115, G13-117, G13-118, G13-123 G17-135, G17-136, G17-137 and check GRDB 15) showed good tolerance to lodging $(0 \%)$, while the other twenty eight percentage of strains including the check variety (GRDB 13) showed lodging incidence ranging from 2-36\% (Figure 1). Strains G13-116 and G 17-138 shows a significant higher lodging incidence when compared to the other strains tested (Table 2).

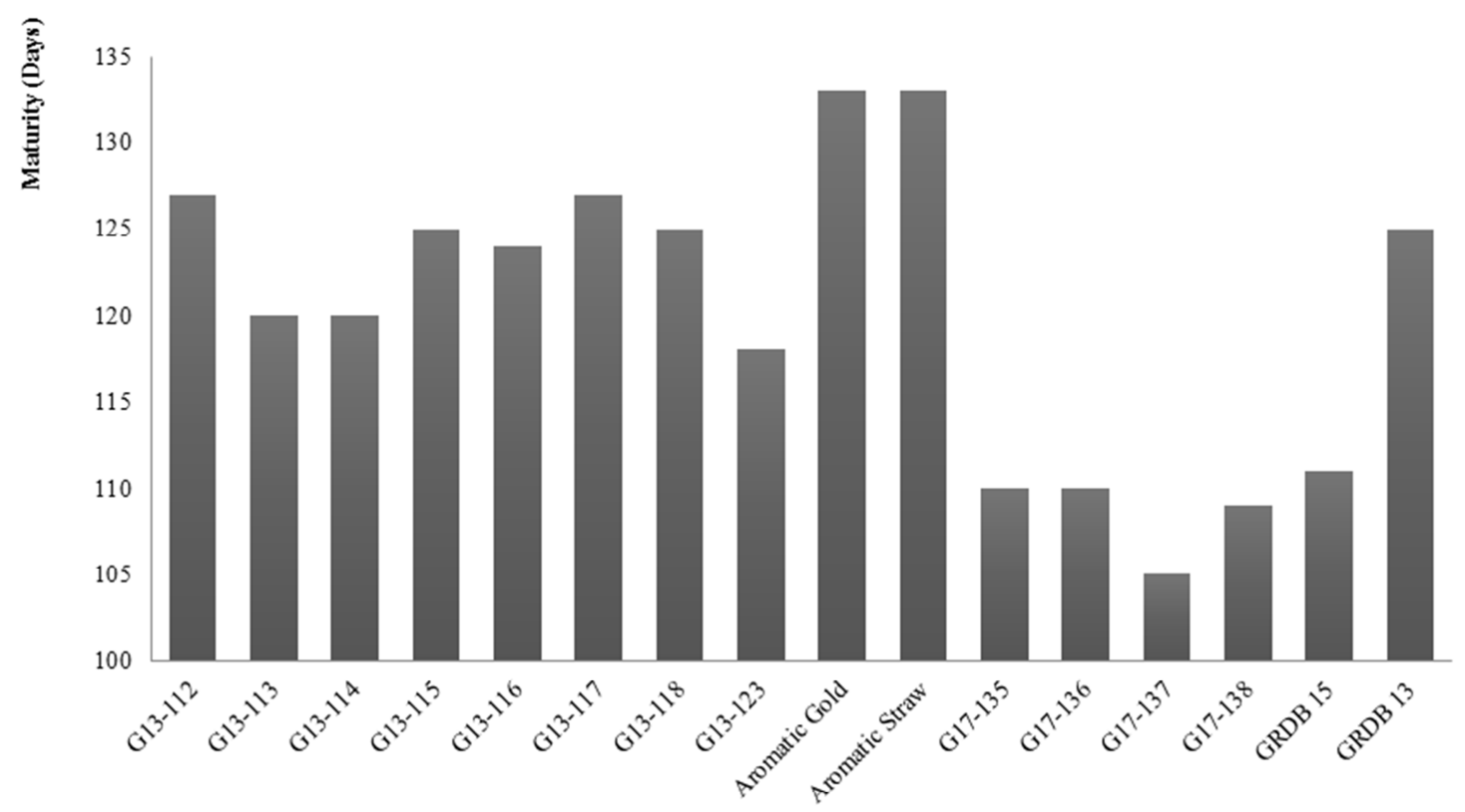

Strains

Figure 2. Maturity comparison for strain tested during the spring crop of 2019. 
Over seventy-two percent of the strains tested including the check variety (GRDB 13) ranged from 120 to 133 days to maturity. Strains Aromatic Gold and Aromatic Strew took the longest to mature with 133 days while the G17-138 matured in the shortest time with 105 days (Figure 1). Strains such as, G17-137, G17-138, G17-136 and G17-135 mature between 105 and 110 days which is significantly lower when compared to GRDB 13 (Table 2). All strains tested in this experiment matured much earlier that those studied by $\mathrm{S}$. Kumar and I. Deo [12] where they studied 88 advance aromatic lines in India and observed maturity between 158 to 183 days after sowing.
The comparison of plant high for the entries tested showed that fourteen strains including the check varieties recorded a desirable plant height which is between $85 \mathrm{~cm}$ to $98 \mathrm{~cm}$ tall. The tallest plant height was observed in strain G 17-136 $(97.87 \mathrm{~cm})$ while the shortest beings strain G 13- 114 (79.03 cm) (Table 2). Strains G 13-113 and G13-114 recorded a significantly lower plant height when compared to the other entries with $79.50 \mathrm{~cm}$ and $79.30 \mathrm{~cm}$ respectively (Table 2). This vast difference in plant height from $79.30 \mathrm{~cm}$ to 97.87 $\mathrm{cm}$ in plant height for the various strains according to $[3,10$, $11,16,19]$ may be due to the genetic characteristics of each variety/strain.

Table 2. Grain yield, lodging, maturity and plant height comparison for strain tested during the spring crop of 2019.

\begin{tabular}{|c|c|c|c|c|}
\hline Strains & Yield $\left(\mathrm{kg} / \mathrm{ha}^{-1}\right)$ & Lodging (\%) & Maturity (days) & Plant Height $(\mathrm{cm})$ \\
\hline G13-112 & $6847.37^{\text {ef }}$ & $8.33^{b}$ & $127.00^{\mathrm{a}}$ & $94.93^{\mathrm{ab}}$ \\
\hline G13-113 & $7840.47^{\mathrm{bc}}$ & $0.00^{\mathrm{b}}$ & $120.00^{c}$ & $79.50^{f}$ \\
\hline G13-114 & $7761.83^{\text {bcd }}$ & $0.00^{\mathrm{b}}$ & $120.00^{c}$ & $79.30^{f}$ \\
\hline G13-115 & $6662.20^{\mathrm{f}}$ & $0.00^{\mathrm{b}}$ & $125.00^{\mathrm{b}}$ & $93.37^{\mathrm{ab}}$ \\
\hline G13-116 & $7103.03^{\text {cdef }}$ & $36.67^{\mathrm{a}}$ & $123.67^{b}$ & $92.77^{\mathrm{abc}}$ \\
\hline G13-117 & $7174.23^{\text {cdef }}$ & $0.00^{\mathrm{b}}$ & $127.00^{\mathrm{a}}$ & $95.40^{\mathrm{ab}}$ \\
\hline G13-123 & $6587.00^{f}$ & $0.00^{\mathrm{b}}$ & $117.67^{\mathrm{d}}$ & $91.23^{\mathrm{e}}$ \\
\hline Aromatic Gold & $6988.87^{\text {def }}$ & $0.00^{\mathrm{b}}$ & $133.33^{\mathrm{e}}$ & $85.03^{b c}$ \\
\hline Aromatic Straw & $6971.50^{\text {def }}$ & $0.00^{\mathrm{b}}$ & $133.33^{\mathrm{e}}$ & $85.70^{\text {de }}$ \\
\hline G17-135 & $7271.50^{\text {cdef }}$ & $1.67^{\mathrm{b}}$ & $110.67^{f}$ & $97.57^{\mathrm{a}}$ \\
\hline G17-136 & $7144.10^{\text {cdef }}$ & $0.00^{\mathrm{b}}$ & $110.67^{f}$ & $97.87^{\mathrm{a}}$ \\
\hline G17-137 & $7322.27^{\text {cdef }}$ & $0.00^{\mathrm{b}}$ & $105.00^{\mathrm{g}}$ & $90.73^{\text {bcd }}$ \\
\hline G17-138 & $7526.50^{\text {bcde }}$ & $31.67^{\mathrm{a}}$ & $109.33^{f}$ & $95.13^{\mathrm{ab}}$ \\
\hline GRDB 13 & $8270.30^{a b}$ & $10.00^{b}$ & $125.00^{b}$ & $91.53^{\mathrm{bc}}$ \\
\hline Grand Mean & 7340.21 & 5.52 & 117.71 & 90.79 \\
\hline C. $V$ & 12.98 & 12.06 & 0.77 & 3.46 \\
\hline P. Value (0.05) & 0.06 & 0 & 0 & 0 \\
\hline F. Value & 1.88 & 5.92 & 193.83 & 10.35 \\
\hline
\end{tabular}

Table 3. Some other agronomic parameter for strain tested during the spring crop of 2019.

\begin{tabular}{|c|c|c|c|c|}
\hline Strains & Productive tiller $\left(\mathbf{m}^{2}\right)$ & Spikelet fertility (\%) & Panicle length Length $(\mathrm{cm})$ & 1000-grain wright Wt. (g) \\
\hline G13-112 & $464.00^{\text {ab }}$ & $85.97^{\text {abc }}$ & $22.12^{\text {abcd }}$ & $30.80^{\text {bcd }}$ \\
\hline G13-113 & $479.33^{\mathrm{ab}}$ & $75.50^{\text {def }}$ & $18.98^{\mathrm{d}}$ & $27.20^{\mathrm{efg}}$ \\
\hline G13-114 & $456.00^{\mathrm{abc}}$ & $83.90^{\text {bcd }}$ & $25.21^{\mathrm{abc}}$ & $28.33^{\text {efg }}$ \\
\hline G13-115 & $483.33^{a}$ & 72.80 ef & $24.12^{\text {abcd }}$ & $28.87^{\text {def }}$ \\
\hline G13-116 & $469.33^{a b}$ & $73.60^{\text {ef }}$ & $25.88^{\mathrm{ab}}$ & $26.93^{\mathrm{fg}}$ \\
\hline G13-117 & $483.33^{\text {a }}$ & $68.23^{\mathrm{f}}$ & $25.00^{\mathrm{abc}}$ & $24.53^{h}$ \\
\hline G13-118 & $448.67^{\mathrm{abc}}$ & $71.63^{\text {ef }}$ & $25.67^{\mathrm{ab}}$ & $28.00^{\mathrm{efg}}$ \\
\hline G13-123 & $427.33^{\text {abcd }}$ & $83.87^{\text {bcd }}$ & $22.52^{\text {abcd }}$ & $28.33^{\mathrm{efg}}$ \\
\hline Aromatic Gold & $420.00^{\text {abcd }}$ & 79.40 bcde & $27.65^{\mathrm{a}}$ & $31.80^{\mathrm{ab}}$ \\
\hline Aromatic Straw & $391.33^{\mathrm{cd}}$ & 80.23 bcd & $22.01^{\mathrm{bcd}}$ & $29.47^{\text {cde }}$ \\
\hline G17-135 & $377.33^{d}$ & 79.30 bcde & $19.78^{\mathrm{cd}}$ & $32.27^{\mathrm{ab}}$ \\
\hline G17-136 & $447.33^{\mathrm{abc}}$ & $76.73^{\text {cdef }}$ & $20.97^{\text {bcd }}$ & $33.13^{\mathrm{a}}$ \\
\hline G17-137 & $418.00^{\text {bcd }}$ & $95.00^{\mathrm{a}}$ & $23.18^{\text {abcd }}$ & $31.20^{\mathrm{abc}}$ \\
\hline G17-138 & $455.33^{\mathrm{abc}}$ & $87.17^{\mathrm{ab}}$ & $21.74^{\mathrm{bcd}}$ & $31.80^{\mathrm{ab}}$ \\
\hline GRDB 15 & $438.67^{\text {abcd }}$ & $86.37^{\mathrm{abc}}$ & $22.57^{\text {abcd }}$ & $26.23^{\text {gh }}$ \\
\hline GRDB 13 & $433.33^{\text {abcd }}$ & $84.87^{\text {bcd }}$ & $20.79^{\text {bcd }}$ & $28.87^{\text {def }}$ \\
\hline Grand Mean & 443.29 & 80.29 & 23.01 & 29.24 \\
\hline C. V & 8.77 & 7.26 & 14.46 & 4.76 \\
\hline P. Value (0.05) & 0.0616 & 0.0003 & 0.1456 & 0 \\
\hline F. Value & 1.93 & 4.35 & 1.56 & 9.08 \\
\hline
\end{tabular}




\subsection{Productive Tillers}

All entries in this trial performed well above the required effective tillers per square meter ( 350 tillers $\mathrm{m}^{2}$ ). The number of effective tillers was found to be within the range of 377 to 483 tillers per meter square. Strains G 13-115 and G 13-117 obtained the most number of effective tillers (483) as compared to G 17135 with the least (377). There was no significant difference found between strains tested with the exception of aromatic straw and G17-135 being lower (Table 3).

\subsection{Spikelet Fertility}

Strain G17-137 produced the highest significant number of fertile grains per panicle with $95 \%$ fertility, but was on par with G13-112 (85.9\%), G17-138 (87.1) and check GRDB 15 $(86.3 \%)$, while strain G13-117 produce the lowest number of fertile grains per panicle at $69.2 \%$ (Table 3). According to Standard Evaluation System for Rice, $5^{\text {th }}$ Edition, 2013, Strain G17- 137 was classified as highly fertile while G13-115, G13116, G13- 117 and G13- 118 were found to be partly fertile. The other eleven (11) strains including the two check varieties were deemed as fertile. S. Kumar and I. Deo (2015) studied 88 advance aromatic lines in India shows similar results with spikelet fertility ranging from 65.9 to $83 \%$.

\subsection{Panicle Length}

The longest panicle length $(27.65 \mathrm{~cm})$ was obtained in the strain Aromatic Gold which was significantly longer to that of strains G13-113, aromatic straw, G17-135, G17-136 and G13138. Strain G13-113 recorded the shortest panicle $(18.98 \mathrm{~cm})$ among the sixteen entries evaluated (Table 3 ). This variation might be heredity as it may be directly related to genetic characteristics of those varieties/ strains. Similar result was recorded by ldris and Motin (1990) and Golam et al., 2011 [7].

\subsection{0-grain Weight}

In table 3, it can be noted that G17-136 obtain the heaviest grain weight $(33.13 \mathrm{~g})$ for every 1000 grains weighted whereas, G13-117 obtained the lowest weight $(24.53 \mathrm{~g})$. The high yielding check variety (GRDB 15) and strain G13-117 produces grain that are significantly lower in weight when compared to the rest of entries tested. In 2015, S. Kumar and I. Deo studied 88 advance aromatic lines in India and obtained an average 1000 grain weight of $14.70 \mathrm{~g}$ which is far lower $(29.24 \mathrm{~g})$ than what the fourteen aromatic strains in this trial obtained [12].

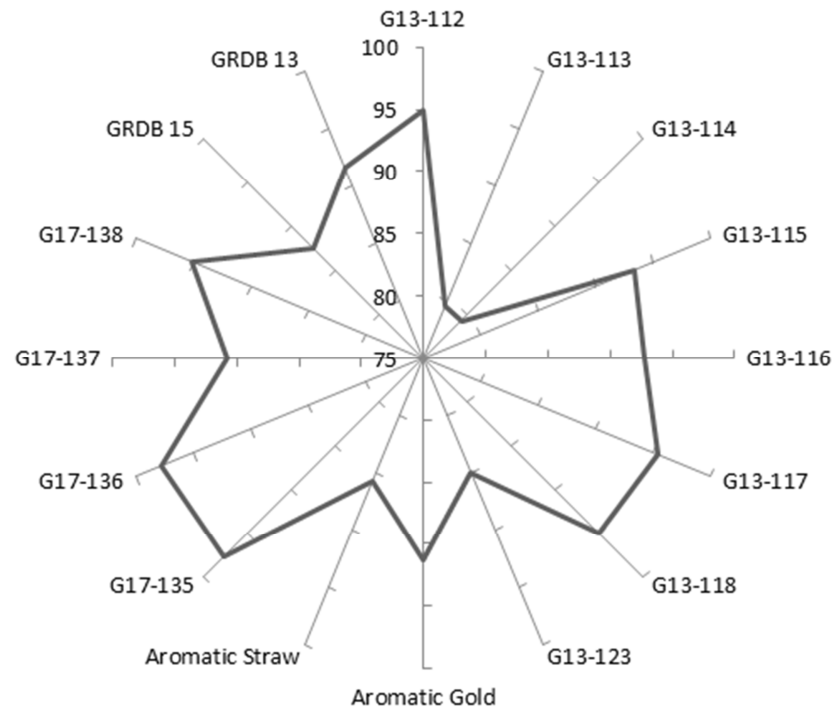

Figure 3. Plant height comparison for strain tested during the spring crop of 2019.

Table 4. Comparison of milling characters for strain tested during the spring crop of 2019.

\begin{tabular}{|c|c|c|c|c|c|c|c|}
\hline S. $\mathbf{N}$ & Strain & HRR paddy & HRR cargo & Chalkiness & Expansion Width (\%) & Expansion Length (\%) & ASV \\
\hline 1 & G13-112 & $50.20^{\text {bcd }}$ & $77.84^{\text {bcde }}$ & $0.10^{\mathrm{b}}$ & $67.06^{\mathrm{ab}}$ & $66.98^{\mathrm{c}}$ & $5.33^{\mathrm{a}}$ \\
\hline 2 & G13-113 & $56.48^{\mathrm{ab}}$ & $83.01^{\text {abcd }}$ & $0.00^{\mathrm{b}}$ & $71.31^{\mathrm{a}}$ & $70.47^{\mathrm{abc}}$ & $3.67^{\mathrm{abc}}$ \\
\hline 3 & G13-114 & $53.99^{\mathrm{abc}}$ & $81.70^{\text {abcde }}$ & $0.40^{\mathrm{a}}$ & $69.86^{\mathrm{a}}$ & $73.28^{\mathrm{ab}}$ & $4.00^{\mathrm{abc}}$ \\
\hline 4 & G13-115 & $50.82^{\text {bcd }}$ & $83.65^{\mathrm{abc}}$ & $0.10^{\mathrm{b}}$ & $70.034^{\mathrm{a}}$ & $70.12^{\mathrm{abc}}$ & $4.67^{\mathrm{ab}}$ \\
\hline 5 & G13-116 & $52.07^{\mathrm{abcd}}$ & $85.22^{\mathrm{a}}$ & $0.13^{\mathrm{b}}$ & $69.98^{\mathrm{a}}$ & $67.69^{\mathrm{bc}}$ & $4.33^{\mathrm{abc}}$ \\
\hline 6 & G13-117 & $42.16^{\mathrm{ef}}$ & $78.09^{\text {bcde }}$ & $0.10^{\mathrm{b}}$ & $70.99^{\mathrm{a}}$ & $68.063^{\mathrm{bc}}$ & $4.00^{\mathrm{abc}}$ \\
\hline 7 & G13-118 & $49.56^{\mathrm{cd}}$ & $84.56^{\mathrm{a}}$ & $0.10^{\mathrm{b}}$ & $66.69^{\mathrm{ab}}$ & $67.79^{\mathrm{bc}}$ & $4.00^{\mathrm{abc}}$ \\
\hline 9 & Aromatic Gold & $54.56^{\mathrm{abc}}$ & $77.23^{\text {cde }}$ & $0.03^{\mathrm{b}}$ & $68.28^{\mathrm{ab}}$ & $71.01^{\mathrm{abc}}$ & $4.33^{\mathrm{abc}}$ \\
\hline 10 & Aromatic Straw & $54.72^{\mathrm{abc}}$ & $80.38^{\text {abcde }}$ & $0.03^{b}$ & $64.91^{\mathrm{ab}}$ & $70.47^{\mathrm{abc}}$ & $3.33^{\mathrm{bc}}$ \\
\hline 11 & G17-135 & $51.37^{\text {bcd }}$ & $76.33^{\mathrm{e}}$ & $0.10^{\mathrm{b}}$ & $71.37^{\mathrm{a}}$ & $69.61^{\mathrm{bc}}$ & $4.33^{\mathrm{abc}}$ \\
\hline 12 & G17-136 & $39.83^{\text {ef }}$ & $55.77^{\mathrm{f}}$ & $0.13^{b}$ & $69.58^{\mathrm{a}}$ & $70.25^{\mathrm{abc}}$ & $4.00^{\mathrm{abc}}$ \\
\hline 13 & G17-137 & $56.32^{\mathrm{ab}}$ & $76.96^{\mathrm{de}}$ & $0.07^{\mathrm{b}}$ & $61.50^{\mathrm{b}}$ & $69.26^{\mathrm{bc}}$ & $4.00^{\mathrm{abc}}$ \\
\hline 14 & G17-138 & $36.63^{\mathrm{f}}$ & $56.69^{\mathrm{f}}$ & $0.40^{\mathrm{a}}$ & $63.62^{\mathrm{ab}}$ & $75.90^{\mathrm{a}}$ & $3.67^{\mathrm{abc}}$ \\
\hline 15 & GRDB 15 & $58.41^{\mathrm{a}}$ & $83.90^{\mathrm{ab}}$ & $0.10^{\mathrm{b}}$ & $64.79^{\mathrm{ab}}$ & $68.31^{\mathrm{bc}}$ & $3.00^{\mathrm{bc}}$ \\
\hline \multicolumn{2}{|c|}{ Grand Mean } & 50.43 & 77.47 & 0.13 & 67.84 & 69.85 & 3.96 \\
\hline \multicolumn{2}{|c|}{ C. V } & 7.69 & 4.99 & 104.98 & 6.89 & 5.33 & 26.43 \\
\hline \multicolumn{2}{|c|}{ P. Value $(0.05)$} & 0 & 0 & 0.04 & 0.33 & 0.73 & 0.4 \\
\hline \multicolumn{2}{|c|}{ F. Value } & 7.82 & 15.55 & 2.07 & 1.19 & 0.12 & 1.09 \\
\hline \multicolumn{2}{|c|}{ SEM } & 2.2399 & 2.2325 & 0.0796 & 2.6977 & 2.1506 & 0.604 \\
\hline \multicolumn{2}{|c|}{ SEM (diff.) } & 3.1677 & 3.1572 & 0.1125 & 3.8151 & 3.0415 & 0.8542 \\
\hline
\end{tabular}




\subsection{Milling Recoveries}

In the Head Rice Recovery (HRR) from paddy, seventy five percent $(75 \%)$ of the all stains tested recorded more the $50 \%$ recovery. The GRDB 13 (check variety) along with G 17-138, G 17-136 and G 13-117 obtained less than 50\% recovery from paddy. Strain G 13-113 recorded the highest recovery of the aromatic strain tested while statically G13-117, G17-136 and G17-138 recorded the lowest head rice recovery from paddy (Table 4). In 2012 Parikh, M., Rastogi, N. K. and Sarawgi, A. $\mathrm{K}$. studied 36 aromatic rice genotypes in Bangladesh and observed a 50-69\% head rice recovery from paddy [13].

\subsection{Chalkiness of Endosperm}

The chalkiness of the rice grain was classified into white belly, white center and white back according to Standard Evaluation System for Rice, $5^{\text {th }}$ Edition, 2013. Among the strains tested, G13-113 is the only strain that showed $0 \%$ chalkiness whereas strains G13-114 and G17-138 recorded the highest percentage. All the other aromatic strains showed less than 20\% chalkiness (table 4). Bhonsle S. J. [2] evaluated 14 aromatic rice varieties in India and attained chalky grains ranging from 0 to $64.36 \%$. The chalky grains reduce the palatability of cooked products, thus the presence of more than $20 \%$ chalkiness in rice kernels is not acceptable in world markets [4].

\subsection{Grain Expansion After Cooking}

All strains expanded more the $60 \%$ in length and width. Strain G17-138 and G13-114 expanded the most in length with $75.90 \%$ and $73.28 \%$ respectively, which was significantly higher when compared to the check variety (GRDB 13); while the G13-112 showed the least expansion in length with $66.99 \%$. With respect to the expansion in grain width, G13-113, G13-117 and G17-135 recorded the highest expanding property with more that $71 \%$ and G17-137 recorded the lowest expansion percentage in width $(61.50 \%)$ and statically, it is the lowest expansion percentage in width when compared to the other entries in the trial (Table 4).

\subsection{Alkali Digestion}

The Alkaline spreading value (ASV) allows for estimation of the gelatinization temperature and is partly associated with the amylose content of the starch. Low amylose rice grains allow fast disintegration whereas the high amylose grains retain its shape. As indicated in table 4, G13-112 has a high ASV (5.33) which is significantly different to G13-123 the high yielding check variety (GRDB 15). The majority of these aromatic strains have an ASV ranging from 4 to 4.67. Chowdhury et al 2016, studied 65 rice genotypes where he obtained similar results (ASV ranging from 3 to 6.06) [5].

\section{Conclusion}

During the spring crop of 2019, 14 elite aromatic lines were evaluated at the Rice Research Station, Burma, Mahaicony, East Coast Demerara. These lines were observed and the several findings were made. From data recorded, it was found that strains G13-113, G13-114 and G17-138 yielded at par with the check variety GRDB 13 with good resistance to lodging. However, G13- 116 and G17-138 did not follow this trend and had a significantly higher lodged incidence $(>30 \%)$ when compared to the other test entries. The check variety GRDB 13 has a maturity period of 125 days however; strains G13-113, G13-114, G 13-116, G13123, G17-135, G17-136, G 17-137 and G17-138 recorded a significantly shorter maturity period.

The grain length expansion of strains G17-138 and G13114 were significantly higher while milling recovery was significantly greater for G13-113, G13-124, Aromatic gold, Aromatic straw and G17-137 when compared to the GRDB 13. All strains evaluated showed low levels of chalkiness $(<0.4 \%)$.

It was observed that strains G13-113 and G13-114 show promising results when compared to the GRDB 13 and the other strains since they have a shorter maturation period, better yield capability, tolerance to lodging and a higher Head Rice Recovery from paddy.

\section{Recommendations}

The study identified significant better performance of the important characters among the strains tested compared to the GRDB 13. Repeat of studies for at least one to two season more to confirm stability of traits and the superiority of the promising strains for possible large scale testing in farmers field.

\section{Declarations}

\section{Availability of Data and Material}

The data generated and analysed in this study is available in this publish manuscript.

\section{Competing Interests}

There is no potential conflict of interest to declare.

\section{Authors' Contributions}

First author Mahendra Persaud design and execute the experiments, second authors analyzed the data and drafted the manuscript. Fourth provide technical advice, format and edit the manuscript. All other authors provide moral support, technical advice, read and agree with the content of the manuscript.

\section{Acknowledgements}

The first author is thankful to Guyana Rice Development Board (GRDB) for providing him with the necessary funding and facility to conduct this research work at the GRDB, Rice 
Research Station, Burma and within the rice industry in Guyana.

\section{References}

[1] Akram, M (2009). Aromatic Rices of Pakistan- A Review, Pakistan Journal of Agri. Research, Vol 22, No 3-4: 154-160.

[2] Bhonsle S. J. (2010). Grain Quality Evaluation and Organoleptic Analysis of Aromatic Rice Varieties of Goa, India. Journal of Agricultural Science. Vol. 2 (3): 99-107.

[3] Bony, M. H., Paul, S. K.; Kader, M. A. and Sarkar, M. A. R. (2015). Yield performance of Boro rice in response to USG. J. Bangladesh Agril. Univ., 13 (1): 13-17.

[4] Cheng, F. M., Zhong, L. J., Wang, F., and Zhang, G. P. (2005). Differences in cooking and eating properties between chalky and translucent parts in rice grains. Food Chemistry, 90: 39-46.

[5] Chowdhury B. D., Nath A., and Dasgupta T. (2016). Characterization and variability analysis of Rice genotypes with reference to Cooking Quality Parameters. IOSR Journal of Agriculture and Veterinary Science (IOSR-JAVS) e-ISSN: 23192380, p-ISSN: 2319-2372. Volume 9, Issue 4 Ver. II: 08-12.

[6] FAO. (2019). Food and Agriculture Organization Rice Price Update. https://www.acpaarrozcorrientes.org.ar/Paginas/FAORice-Price-Update-Jun-2019.pdf.

[7] Golam Faruq, Yin Y. H, Masitah A., Afnierna N., Majid N. A. and Khalid N. (2011). Analysis of aroma and yield components of aromatic rice in Malaysian tropical environment. AJCS 5 (11): 1318-1325 (2011) ISSN: 18352707.

[8] Ghosh P, Roychoudhury A (2018) Differential levels of metabolites and enzymes related to aroma formation in aromatic indica rice varieties: comparison with non-aromatic varieties. 3 Biotech 8: 25.

[9] Hossain, M. F., Islam, M. S. (2008). Yield and quality performance of some aromatic rice varieties of Bangladesh. J. Agrofor. Environ. 2 (2): pp. 155-158.

[10] Islam, M. S.; Paul, S. K. and Sarkar M. A. R. (2014). Varietal performance of modern transplant Aman rice subjected to level of nitrogen application. J. Bangladesh Agril. Univ., 12 (1): 55-60.
[11] Jisan, M. T.; Paul, S. K. and Salim, M. (2014). Yield performance of some transplant Aman rice varieties as influenced by different level of nitrogen. J. Bangladesh Agril. Univ., 12 (2): 321-324.

[12] Kumar, S., and Deo, I. (2015). Studies on genetic variability, heritability and genetic advance in advance lines of Kalanamak aromatic rice (Oryza sativa L.). Eco. Env. \& Cons. 22 (2): pp. 891-895.

[13] Parikh, M., Rastogi, N. K. and Sarawgi, A. K. (2012). Variability in grain quality traits of aromatic rice (Oryza sativa L.). Bangladesh J. Agril. Res. 37 (4): pp. 551-558.

[14] Persaud. M, (2016). Aromatic rice production to be increased. Ministry of Agriculture. https://agriculture.gov.gy/2016/11/03/aromatic-riceproduction-to-be-increased/

[15] Rashid, M., Anup Kumar and Ghosh, N. K. (2017). Yield performance of seven aromatic rice varieties of Bangladesh. International Journal of Agriculture and Environmental Research ISSN: 2455-6939 Vol: 03, No: 2, pp. 2637-2642.

[16] Sarkar, S. K.; Sarkar M. A. R.; Islam N. and Paul S. K. (2014). Yield and quality of aromatic fine rice as affected by variety and nutrient management. J. Bangladesh Agril. Univ., 12 (2): pp. 279-284.

[17] Seoraj, N. (2021, January 5). Rice earnings top \$51B. Guyana Chronicle the nation's paper. https:/guyanachronicle.com/2021/01/05/rice-earnings-top-51b/

[18] Singh R. K., Singh U. S. and Khush G. S. (2000). Aromatic Rices. Mohan Primlani for Oxford \& IBH Publishing Co. Pvt. Ltd., 66 Janpath, New Delhi 110001.

[19] Tyeb, A., Paul, S. K. and Samad, M. A. (2013). Performance of variety and spacing on the yield and yield contributing characters of transplanted Aman rice. J. Agrofor. Environ., 40 (4): 595-597.

[20] Redoña, E. D. (2013). Standard Evaluation System for Rice. $5^{\text {th }}$ Ed. International Rice Research Institute, P. O. Box 933, Manila, Philippines. pp. $16 \& 44$.

[21] Verma, D. K., Srivastav, P. P. (2020). Extraction, Identification and Quantification Methods of Rice Aroma Compounds with Emphasis on 2-Acetyl-1-Pyrroline (2-AP) and Its Relation with Rice Quality: A Comprehensive Review. Food Rev Inter. https://doi.org/10.1080/87559129.2020.1720231. 